\title{
ポリウレタンフォームプラグによる大気中のフタル酸 エステルの捕集
}

山崎 裕康, 桑田一弘*

(1976 年 4 月 15 日受理)

\begin{abstract}
ガラスフォイバーフィルターとポリウレタンフォームプラグを組み合わせることによって大気中のフ タル酸エステル，すなわちフタル酸ジプチル (DBP), フタル酸ジへプチル (DHP), フタル酸ジエチ ルヘキシル (DEHP) を効率よく捕集することができた. ガラスフィイバーフィルターとポリウレタン フォームプラグを内径 $20 \mathrm{~mm}$ ，長さ $14 \mathrm{~cm}$ のガラス管に装てんし，このガラス管を通して大気を $28 \mathrm{l}$ 分で 48 時間吸引した。捕集したフタル酸エステルを $5 \%$ 石油エーテル含有 $n$-ヘキサンで抽出し, 濃 縮し, 硫酸処理した後, 電子捕獲型検出器付きガスクロマトグラフで定量した。 DBP，DHP，DEHP の平均回收率は，それぞれ，99.1\%，93.3\%，92.9\% であり，大気を $80 \mathrm{~m}^{3}$ 吸引したときの検出限界 は，それぞれ，(0.0041〜0.011) $\mu \mathrm{g} / \mathrm{m}^{3}, 0.001 \mu \mathrm{g} / \mathrm{m}^{3} ，(0.0019 \sim 0.0036) \mu \mathrm{g} / \mathrm{m}^{3}$ であった。
\end{abstract}

\section{1 緒}

フタル酸エステル (PAE) は塩化ビニルなどの可塑棛 として大量に用いられており, その環境污染が問題にな

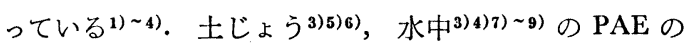
測定例は多いが，大気中の測定例 ${ }^{3)}$ は少ない. その原因 は大気中の PAE の捕集方法にあると考えられる.

PAE の微量分析には一般に電子捕獲型検出器付きガ スクロマトグラフ (ECD-GG) 法が用いられる4)10) 15) が, ECD が高感度であるために, 実験器具, 試薬, 実験室 内空気からの污染によるブランクが問題である10) 15).

従って環境大気中の PAE を測定するときには，ブラン クの影響を少なくするために大量の大気を吸引する必要 がある. 従来から用いられている PAE の捕集方法に は，インピンジャー, バブラーによる湿式捕集方法16)17), フロリジルにグリセリンをコーティングしたものを用い た固相吸着法1011)などがある。しかし，これらの捕集方 法では大量の大気を吸引できない $\left\{(1 \sim 10) \mathrm{m}^{3}\right\}$ ので, 環境大気中の PAE の捕集方法としては十分ではない.

最近, ポリウレタンフォームプラグが水中の PAE ${ }^{18)}$, $\mathrm{PCB}$, 有機塩素系農薬19) 21), 海上大気中の $\mathrm{PCB}^{22}$ の 捕集に用いられ，興味ある結果が得られている.

著者らはガラスフォイバーフィルターとポリウレタン

* 大阪府公害監視センター : 大阪府大阪市東成区中道 $1-3-62$
フォームプラグを組み合わせて大気中の PAE, 特に我 が国で生産量の多い23) フタル酸ジブチル (DBP), フタ ル酸ジヘプル (DHP), フタル酸シエチルヘキシル (DEHP) の捕集方法について検討した. その結果，ポ リウレタンフォームプラグは通気抵抗が少ないので, 大 量の大気を吸引でき，しかも，ガラスフォイバーフィル ターを通過する PAE を効率よく捕集することが分かっ たので報告する。

\section{2 試薬及び装置}

\section{1 試 薬}

試薬は次の市販品をそのまま用いた。 $n$ 一キキサン: 和光純薬残留農薬用 $n$ 一へキサン 300 石油エーテル: 和光純薬残留農薬用 アセトン：試薬特級

濃硫酸 : 試薬特級

DBP, DHP, DEHP 標準試薬 : 和光純薬 PAE 標準 品

\section{2 装置及び器具}

使用した装置, 器具及びその条件は次のとおりである. ガスクロマトグラフ : ECD $\left({ }^{3} \mathrm{H}\right)$ 付きバリフン 2100 型

カラム: ジメチルシラン処理したガラス管（内径 2 $\mathrm{mm}$, 長さ $1.5 \mathrm{~m}$ )

液相: $2 \%$ OV-225

担体: バシポート $30\{(100 〜 120)$ メッシュ\} 
キャリアーガス:窒素 $30 \mathrm{ml} /$ 分

カラム温度: $205^{\circ} \mathrm{C}$, 注入口温度: $210^{\circ} \mathrm{C}$, 検出部温 度 : $220^{\circ} \mathrm{C}$

吸引ポンプ: エノモトミクロポンプ DM-480 型

恒温そう： $500^{\circ} \mathrm{C}$ 程度まで加熱できるもの.

ガラスファイバーフィルター：ワットマン GF/A を 直径 $20 \mathrm{~mm}$ に打ち抜き, 恒温そう中で $420^{\circ} \mathrm{C}, 15$ 時 間以上加熱し，使用直前に室温むで冷却した。

ポリウレタンフォームプラグ: 厚み $50 \mathrm{~mm}$ のポリウ レタンフォームシート（エーテルタイプ，密度約 0.024 $\left.\mathrm{g} / \mathrm{cm}^{3}\right)$ を直径 $23 \mathrm{~mm}$ の円筒状に打ち抜いたもの.

活性炭カラム：和光純薬クロマトグラフ用活性炭をス テンレス管（内径 $30 \mathrm{~mm}$, 長さ約 $10 \mathrm{~cm}$ ) に充てえし, 窒素気流中 $\left(50 \mathrm{ml} /\right.$ 分) で $200^{\circ} \mathrm{C} ， 10$ 時間加熱後使用 した。

\section{3 実験 操作}

\section{1 実験器具の洗浄}

実験器具の洗浄は次のとおりである.

3.1.1 ガラス器具類, サポート 超音波洗浄器で洗 浄後, 水洗いし，恒温そう内で $420^{\circ} \mathrm{C} て ゙ 15$ 時間以上 加熱し，使用直前に室温まで泠却した。

3.1.2 メスフラスコ，テフロン管 濃硫酸に浸せき した後, 水, アセトン, $n$-ヘキサンの順に洗浄し, 風乾 した.

3.1.3 ポリゥレタンフォームプラグ ポリウレタン フォームプラグ（直径 $23 \mathrm{~mm}$, 長さ $50 \mathrm{~mm}$, 密度約 $\left.0.024 \mathrm{~g} / \mathrm{cm}^{3}\right)$ を水，アセトンでもみ洗いした後，石油 エーテルに 1 週間以上浸せきした. その後, アセトン, 石油エーテルで各々 10 時間ソックスレー抽出し, 使用 直前まで $n$-ヘキサンにつけておく，使用時にポリウレ タンフォームプラグを取り出し，コック付き $100 \mathrm{ml} の$ 注射器のシリンダー部に入れる.プランジャーでポリウ レタンフォームプラグを圧縮し， $n$-ヘキサンをしぼり出 す. 石油エーテルで 3 回洗浄した後, シリンダーから取 り出し, 約 1 分間風乾した.

\section{2 大気中の PAE の捕集方法}

ガラスファイバーフィルターと 2 個のポリウレタンフ ォームプラグを Fig. 1 のように装てえした。捕集管の 吸引口を下に向けて大気を約 281 分， 48 時間（約 80 $\left.\mathrm{m}^{3}\right)$ 吸引した。

\section{3 抽出, 分析}

ガラスフォイバーフィルターとポリウレタンフォーム プラグ上に捕集された PAE を約 $65 \mathrm{ml} の 5 \%$ 石油エ 一テル含有 $n$-ヘキサンで 2.5 時間ソックスレー抽出し た. 抽出液を $10 \mathrm{ml}$ に濃縮し, 硫酸処理を行い10)18),

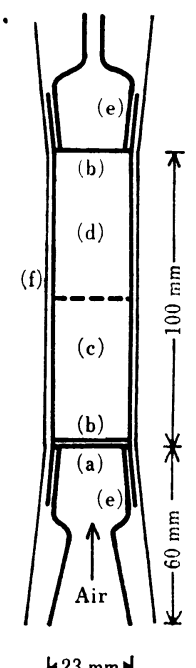

Fig. 1 Collection tube of phthalate esters (a) Glass fiber filter; (b) Support; (c) First polyurethane foam plug; (d) Second polyurethane foam plug; (e) Tapered joint; (f) Aluminum foil

ECD-GG で各PAEを定量した，各PAE の量はPAE ごとに検量線を作成し，相当するピーク高さから求めた．

\section{4 ブランク試験}

Fig. 1 の装置の両端をアルミホイルで覆い，48 時間 放置後, 3.3 の操作を行った．ブランク試験は測定ごと に 3 回並行して行い，それらの平均値をブランク值とし た.

\section{4 結果と洘察}

\section{1 ブランク值と検出限界}

PAE のブランク值は実験日ごとにばらつきがあるが， DBP で $(0.33 \sim 0.90) \mu \mathrm{g}, \mathrm{DEHP}$ で $(0.15 \sim 0.29) \mu \mathrm{g}$, DHP で $0 \mu \mathrm{g}$ あった. DBP，DEHP についてはブラン ク值の 2 倍を定量限界とし，それからブランク值を差し 引いた值を最小検出量とした15)．DHPについては ECD の感度の 2 倍を最小検出量とした．これらの值を大気を $80 \mathrm{~m}^{3}$ 吸引したときの PAE 濃度に換算した值を本方法 の検出限界とすると， DBP て $(0.0041 \sim 0.011) \mu \mathrm{g} / \mathrm{m}^{3}$, DHP で $0.001 \mu \mathrm{g} / \mathrm{m}^{3}$, DEHP で $(0.0019 \sim 0.0036) \mu \mathrm{g} /$ $\mathrm{m}^{3}$ であった。

\section{2 大気中の PAE の捕集方法の検討}

Fig. 1 のガラス管にポリウレタンフォームプラグを 2 個装てんし大気を吸引したとき，2段目のポリウレタン 
フォームプラグ上に PAE が検出された. 又，2段目の ポリウレタンフォームプラグの後ろにガラスフォイバー フィルターを取り付けて吸引したとき，ガラスフォイ バーフィルター上にかなりの粉じんが捕集され，この中 から PAE が検出された. そこで, Fig. 10ようにガラ スファイバーフィルターをポリウレタンフォームプラグ の前に取り付けて大気を吸引した. Table 1 にガラスフ フイパーフィルターとポリウレタンフォームプラグ上に 捕集された PAE の定量結果を示す. ガラスファイバー フィルターを通過した PAE はほとんど1段目のポリウ レタンフォームプラグ上に捕集され，2段目のプラグに は検出されなかった. 従って実際の測定ではガラスファ イバーフィルターと1段目のポリウレタンフォームプラ グ上に捕集された PAEを定量すればよいと思われる. 叉，ガラスフォイバーフィルターを取り付けることによ り，粉じんなどによるポリウレタンフォームプラグの污 染が少なくなるので，3.3 のソックスレー抽出を行った 後プラグを再使用できた.

\section{3 添加回収率試験}

回収率試験での各 PAE の添加量は，ブランク值の影 響を避けるため環境大気中の $\mathrm{PAE}$ 捕集量よりも多くし た. Fig. 2 ( c ) 部のガラスファイバーフィルター上 に DBP，DHP，DEHP をそれぞれ $500 \mu \mathrm{g} / \mathrm{ml}$ を含む $n$-ヘキサン溶液を $40 \mu \mathrm{l}$ (各 PAE $20 \mu \mathrm{g}$ ）添加した. PAE
Table 1 Phthalate esters trapped on the glass fiber filter and the polyurethane foam plugs

\begin{tabular}{|c|c|c|c|c|c|}
\hline \multirow{2}{*}{$\begin{array}{c}\text { Air flow } \\
\text { rate } \\
(1 / \mathrm{min})\end{array}$} & \multirow{2}{*}{$\begin{array}{l}\text { Volume of } \\
\text { air sample } \\
\quad\left(\mathrm{m}^{3}\right)\end{array}$} & \multirow{2}{*}{$\begin{array}{l}\text { Collecting } \\
\text { material }\end{array}$} & \multicolumn{3}{|c|}{ Phthalate ester trapped $(\mu \mathrm{g})$} \\
\hline & & & DBP & DHP & DEHP \\
\hline \multirow{3}{*}{29.6} & \multirow{3}{*}{$85: 2$} & GF & 1.2 & 0.4 & 2.5 \\
\hline & & PU-1 & 3.9 & 0.2 & n.d. \\
\hline & & PU-2 & n. d. & n.d. & n.d. \\
\hline Blanks : I & P $0.35 \mu \mathrm{g}$ & DHP 0.00 & & $0.22 \mu \mathrm{g}$ & n. d : \\
\hline
\end{tabular}

を添加したカラムに清浄空気を通すために，活性炭カラ ムとポリウレタンフォームプラグカラムを Fig. 2 のよ うに PAE 添加カラムの前に取り付けた. 約 $261 /$ 分, 48 時間 (約 $\left.75 \mathrm{~m}^{3}\right)$ 清浄空気を吸引し, PAE 添加カラ ム中のガラスファイバーフィルター, 及びポリウレタン フォームプラグ上に保持されている PAE を定量した.

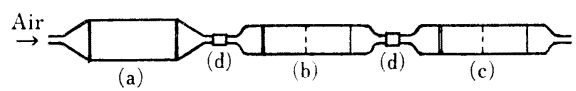

Fig. 2 Apparatus for recovery test of phthalate esters

(a) Air purification column : stainless steel tube packed with activated chacoal; (b) Pre-column as same one as shown in Fig. 1; (c) Collection tube of phthalate esters : $20 \mu \mathrm{g}$ of each phthalate ester was put on the glass fiber filter; (d) Teflon tube

Table 2 Recovery of phthalate esters ${ }^{\dagger}$

\begin{tabular}{|c|c|c|c|c|c|c|c|c|c|c|c|}
\hline \multirow{2}{*}{ Run } & \multirow{2}{*}{$\begin{array}{l}\text { Air flow } \\
\text { rate } \\
(1 / \mathrm{min})\end{array}$} & \multirow{2}{*}{$\begin{array}{c}\text { Volume of } \\
\text { air sample } \\
\quad\left(\mathrm{m}^{3}\right)\end{array}$} & \multirow{2}{*}{$\begin{array}{c}\text { Collecting } \\
\text { material }\end{array}$} & & \multicolumn{3}{|c|}{ Phthalate ester found $(\mu \mathrm{g})$} & & \multicolumn{3}{|c|}{ Recovery (\%) } \\
\hline & & & & & DBP & DHP & DEHP & & DBP & DHP & DEHP \\
\hline \multirow[t]{4}{*}{1} & 25.0 & 72.0 & $G F$ & & 1.3 & 13.3 & 16.0 & & & & \\
\hline & & & PU - 1 & & 18.3 & 6.3 & 3.2 & & & & \\
\hline & & & PU-2 & & n. d. & 0.0 & n.d. & & & & \\
\hline & & & & Total & 19.6 & 19.6 & 19.2 & & 98.0 & 98.0 & 96.0 \\
\hline \multirow[t]{4}{*}{2} & 26.6 & 76.6 & GF & & 0.8 & 13.0 & 15.2 & & & & \\
\hline & & & PU-1 & & 18.2 & 4.8 & 2.6 & & & & \\
\hline & & & PU-2 & & n. d. & 0.0 & n. d. & & & & \\
\hline & & & & 'Total & 19.0 & 17.8 & 17.8 & & 95.0 & 89.0 & 89.0 \\
\hline \multirow[t]{4}{*}{3} & 25.7 & 74.0 & $\mathrm{GF}$ & & 1.8 & 13.5 & 16.5 & & & & \\
\hline & & & PU-1 & & 18.5 & 5.3 & 2.5 & & & & \\
\hline & & & $P U-2$ & & n.d. & 0.0 & n. d. & & & & \\
\hline & & & & Total & 20.3 & 18.8 & 19.0 & & 101.5 & 94.0 & 95.0 \\
\hline \multirow[t]{4}{*}{4} & 26.4 & 76.0 & $G F$ & & 2.3 & 12.8 & 15.0 & & & & \\
\hline & & & $P U-1$ & & 18.0 & 6.0 & 3.1 & & & & \\
\hline & & & $\mathrm{PU}-2$ & & n. d. & 0.0 & n. d. & & & & \\
\hline & & & & Total & 20.3 & 18.8 & 18.1 & & 101.5 & 94.0 & 90.5 \\
\hline \multirow[t]{5}{*}{5} & 25.2 & 72.6 & GF & & 1.7 & 10.9 & 14.4 & & & & \\
\hline & & & PU-1 & & 18.2 & 7.4 & 4.4 & & & & \\
\hline & & & $P U-2$ & & n.d. & 0.0 & n. d. & & & & \\
\hline & & & & Total & 19.9 & 18.3 & 18.8 & & 99.5 & 91.5 & 94.0 \\
\hline & & & & & & & & Average & 99.1 & 93.3 & 92.9 \\
\hline
\end{tabular}

$\dagger 20 \mu \mathrm{g}$ of each phthalate ester put on the GF; Blanks : DBP $0.33 \mu \mathrm{g} ; \quad$ DHP $0.00 \mu \mathrm{g}$; DEHP 0.07 $\mu \mathrm{g}$ (without sulfuric acid treatment); n. d. : Not detectable; GF : Glass fiber filter; PU-1 : First polyurethane foam plug; PU-2: Second polyurethane foam plug 
結果を Table 2 に示す. 蒸気圧の高い DBP がガラス フォイバーフィルターを通過しやすく，低い DEHP は 通過しにくいが，フィルターを通過した PAE はほとん ぞ1段目のポリウレタンフォームプラグ上に捕集されて おり，2段目のプラグには検出されなかった．ガラスフ フイバーフィルターと1段目のポリウレタンフォームプ ラグ上に捕集された PAE を合計して回収率を求めた. DBP，DHP，DEHP の平均回収率は，それぞれ 99.2 \% , 93.3\%，92.9\% であり満足すべき值と考えられる.

\section{4 大気中の PAE の測定例}

大気中の PAE の測定例を Table 3 に示す. 大気中 から検出される PAE のガスクロマトグラムは Fig. 3 の とおりである. DBP, DEHP の存在はガスクロマトグ ラフーマススペクトロメーターで確認した。

Table 3 Phthalate esters in the ambient air samples ${ }^{\dagger}$

\begin{tabular}{clcc}
\hline \multirow{2}{*}{ Date } & \multicolumn{3}{c}{ Phthalate esters found $\left(\mu \mathrm{g} / \mathrm{m}^{3}\right)$} \\
\cline { 2 - 3 } & DBP & DHP & DEHP \\
\hline Feb. 17 19, 1976 & 0.060 & 0.006 & 0.031 \\
Feb. 21 23, 1976 & 0.031 & 0.005 & 0.027 \\
Feb. 25 27, 1976 & 0.025 & 0.006 & 0.036 \\
\hline
\end{tabular}

$\dagger$ Sampling site : Environmental Pollution Control Center (1-3-62, Nakamichi, Higashinari-ku, Osaka-shi, Osaka)

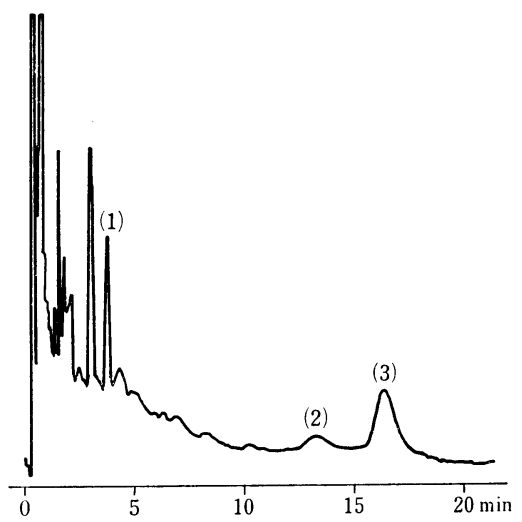

Fig. 3 A gas chromatogram of phthalate esters in the ambient air Peak : (1) DBP, (2) DHP, (3) DEHP

$$
5 \text { 結 論 }
$$

ガラスフォイバーフィルターとポリウレタンフォーム プラグを組み合わせた大気中の PAE の捕集方法は大量 の大気を吸引でき，捕集率，回収率がよいので，ECDGG 法と組み合わせることにより大気中の PAE を高感
度に測定できる. 又，サンプリングに使用したポリウレ タンフォームプラグはソックスレー抽出後再使用できる ので操作が簡単になり，ルーチン分析にも適していると 考えられる.

終わりに，本研究に対して有益な御教示を頂きました 大阪府立公衆衛生研究所鵜川昌弘氏に謝意を表します。

(1975 年 11 月，第 16 回大気污染全国協議会大会にお いて一部発表)

\section{交献}

1) 片瀬隆雄, 半谷高久: 用水と廃水, 14, 8 (1972).

2）片瀬隆雄：環境技術，3，645 (1974).

3) 立川 涼 : 同上, 3, 618 (1974).

4) F. L. Mayer, Jr., D. L. Stalling, J. L. Johnson : Nature, 238, 411 (1972).

5) S. D. Cifrulak : Soil Science, 107, 63 (1969).

6) G. Ogner, M. Schnitzer : Science, 170, 317 (1970).

7) R. A. Hites : J. Chromatogr. Sci., 11, 570 (1973).

8) R. A. Hites : Environ. Health Perspect., 3, 17 (1973).

9) M. Morita, H. Nakamura, S. Mimura : Water Research, 8, 781 (1974).

10)脇本忠明：環境技術，3，659 (1974).

11）立川 涼, 脇本忠明：大気 污染 研究， 8, 607 (1973).

12) G. S. Giam, H. S. Ghan, G. S. Neff : Anal. Chem., 47, 2225 (1975).

13) A. A. Belisle, W. L. Reichel, J. W. Spann : Bull. Environ. Contami. Toxic., 13, 129 (1975).

14) J. Vessman, G. Rietz : J. Chromatogr., 100, 153 (1974).

15)環境庁企画調整局環境保健部保健調査室：昭和 49 年度化学物質環境調査分析方法, 7 (1974).

16) 林 美代子, 林 智: 大阪府立公衆衛生研究所研 究報告 (労衝衛生編), No. 7, 46 (1969).

17）児玉剛則，高井義治：大気 污染研究，9，215 (1974).

18) K. M. Gough, H. D. Gesser : J. Chromatogr., 115, 383 (1975).

19) P. R. Musty, G. Nickless : ibid., 100, 83 (1974).

20) H. D. Gesser, A. Ghow, F. C. Davis: Anal. Lett., 4, 883 (1971).

21) J. W. Bedford : Bull. Environ. Contami. Toxic., 12, 622 (1974).

22) T. F. Bidleman, C. E. Olney : ibid., 11, 442 (1974).

23）通商産業大臣官房調査統計部：化学工業統計年 報, 96 (1974).

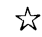

Collection of atomospheric phthalate esters using polyurethane foam plugs. Hiroyasu YAMAsAKI and Kazuhiro Kuwata (Environmental Pollution Control Genter, 1-3-62, Nakamichi, Higashinariku, Osaka-shi, Osaka)

A high volume air sampling approach with combination of a glass fiber filter and polyurethane foam plugs was performed to determine phthalate esters (PAEs), such as dibutyl phthalate (DBP), diheptyl phthalate (DHP) and diethylhexyl phthalate (DEHP), in atomos- 
pheric environments. Air was sampled at $28 \mathrm{l} / \mathrm{min}$ for 48 hours through a glass tube with a glass fiber filter $(20 \mathrm{~mm}$ diameter $)$ and two polyurethane foam plugs (density $0.024 \mathrm{~g} / \mathrm{cm}^{3}, 23 \mathrm{~mm}$ diameter $\times 50 \mathrm{~mm}$ ) in series. The filter and the first plug were extracted in a soxhlet extractor with $5 \%$ petroleum ether in $n$ hexane followed by determination of PAEs by gas chromatography with an electron capture detector. Minimum detectable concentrations of DBP, DHP and DEHP were $(0.0041 \sim 0.011), 0.001$ and $(0.0019 \sim$ $0.0036) \mu \mathrm{g} / \mathrm{m}^{3}$, respectively, when $80 \mathrm{~m}^{3}$ of air was sampled. When $20 \mu \mathrm{g}$ of each PAE was put on the filter and $75 \mathrm{~m}^{3}$ of clean air was passed through the tube, the PAEs moving away from the filter were completely trapped on the first plug and no PAEs were detectable on the second plug. Averaged re- coveries of DBP, DHP and DEHP were 99.1, 93.3 and $92.9 \%$, respectively. Actual levels of DBP, DHP and DEHP found in urban atomosphere at the Environmental Pollution Control Center, Osaka, were $(0.025$ $\sim 0.060), \quad(0.005 \sim 0.006)$ and $(0.027 \sim 0.036) \mu \mathrm{g} / \mathrm{m}^{3}$, respectively.

(Received Apr. 15, 1976)

\title{
Keywords
}

Air pollution

Air sampling technique

ECD-Gas chromatography

Phthalate esters

Polyurethane foam

\section{NMR スペクトル法によるアルキルスルホン酸ナトリウムの分析*}

\author{
橋本茂, 浅野 克二, 永井 敏雄**
}

(1976 年 5 月 17 日受理)

\begin{abstract}
長鎖アルキルスルホン酸ナトリウム (PS) 中のスルホン基位置異性体の定量法について検討した.PS をメチルエステル化して NMR スペクトルを測定したが，スルホン基位置に関する情報を得ることが できなかった．しかしながら，常磁性シフト試薬 $\left[\mathrm{Eu}(\mathrm{dpm})_{3}\right]$ を添加することによって，エステルメ チルシグナルが低磁場側にシフトすることを見いだした．シフトの大きさは，スルホン基位置により異 なり，末端にあるものが最もシフトしやすく内部になるに従って小さくなり，スルホン基位置別にエス テルメチルシグナルを分別することができた．スルホン基位置の異なる混合試料を作り定量分析を行っ たところ，Youden の方法による測定值の標準偏差は 0.94〜1.15 であった. 本法は炭素鎖長の異なる PS 混合物及び分析が困難であったアルキルジスルホネートにも適用できた。
\end{abstract}

\section{1 緒}

長鎖アルキルスルホン酸ナトリウム (PS) は，合成洗 郕用の界面活性郕として用いられている，スルホオキシ 化反応1)によって合成された PS は，種々の位置にスル ホン基を持つ 2 級スルホネートの混合物であるといわれ ている22. これらの異性体を正確に定量することは，反 応解析，物性検討の上からも非带に重要な問題である. $\mathrm{Kupfer}^{2)}$ 及び石井ら ${ }^{3)}$ は，PS を揮発性誘導体にしてガ スクロマトグラフィー (GG) で位置別の定量を行ってい

* スルホン基を含む界面活性郕の組成分析に対する NMR シフト試薬の利用 (I)

** ライオン油脂 (株) 中央研究所 : 東京都江戸川区平井 7-13-12
る.しかしながら，炭素鎖長に分布を持つPSの場合に は，ピークが重複してスルホン基位置別に定量すること が困難であった，又，PS 中に含まれるアルキルジスル ホン酸ナトリウム (DS) の揮発性誘導体は，モノスル ホン酸ナトリウムに比べて沸点が更に高くなり GCで分 析することができなふった。

著者らは，核磁気共鳴スペクトル (NMR) 法による 異性体分析法を検討した. PS のメチルエステル化物 (PSMe) の四塩化炭素溶液に, トリスジピバロイルメタ ナートユーロピウム $\left[\mathrm{Eu}(\mathrm{dpm})_{3}\right]$ を加えると, はじめ は, シングレットであったエステルメチルのシグナルが, 低磁場側にシフトし，しかも，スルホル基の位置により シフトの大きさが異なり，精度よく位置別の定量分析を 